\title{
Best Practices for Management and Empowerment of Street Vendors Padang City in the New Normal Era
}

\author{
Wahyu Pramono ${ }^{1 *}$, Dwiyanti Hanandini ${ }^{2}$
}

\author{
${ }^{I}$ Department of Sociology, Faculty of Social and Political Science, Andalas University \\ ${ }^{2}$ Department of Sociology, Faculty of Social and Political Science, Andalas University \\ Corresponding Author: Email: wahyu.pramonopd2@gmail.com
}

\begin{abstract}
The regional regulation of Padang City No. 3 of 2014 concerning the arrangement and empowerment of street vendors (PKL) has entered the age of 5 years, various implementation practices of these regional regulations have been implemented by the Padang City government. The practice of implementing the PKL structuring and empowerment policies has reduced the intensity of clashes between the Civil Service Police Unit (Satpol PP) and the PKL. This picture shows that what has been done by the city government has more or less fulfilled the expectations of the street vendors. This research will answer the question of how the best practices carried out by the city government in the new normal era in implementing structuring policies and empowering street vendors in the city of Padang so as not to cause resistance to street vendors? The research was conducted in the city of Padang with street vendors as respondents. Data were collected using questionnaires, observation, and document study. The collected data were processed with the Statistic Packet of Social Sciences program. The results show that the best practice of structuring and empowering street vendors in the city of Padang begins with a change in the policy of the Padang city government which places street vendors as part of the source of city disorder (Padang City Regional Regulation number 11 of 2005 concerning Public Order and Peace of the People) becomes part of the city's economic system (Padang City Regional regulation number 3 of 2014 on structuring and empowering street vendors). Street vendors assessed that policy implementation still places more emphasis on structuring rather than empowering street vendors. Good practices carried out by the Padang city government in implementing the policy of structuring and empowering street vendors in creating an atmosphere for street vendors that are clean, orderly, beautiful, comfortable, safe, realizing an integrated arrangement of street vendors in a harmonious, harmonious and balanced manner with sustainable spatial planning, and increasing participation The community in structuring and fostering street vendors is considered to have been achieved by street vendors. Meanwhile, the policy objectives of structuring and empowering street vendors in terms of improving welfare through the development of community trade activities in the informal sector are considered to have not been achieved.
\end{abstract}

Keywords: Good practice, street vendors, policies, structuring, empowerment 


\section{INTRODUCTION}

Public policy is practiced in the form of action. Well-formulated policies can be put into practice properly so that they can produce actions in accordance with the stated policy objectives. Policies can also lead to actions that are not in accordance with the objectives set out in the policy. Practices in the field are often not in line with the policies made. There are various factors related to policy implementation so that it is in line with the policy objectives made.

The policy of structuring street vendors in Padang City is outlined in the Padang City Regional Regulation Number 3 of 2014 concerning Structuring and Empowerment of Street Vendors. In article 3 there are 4 objectives to be achieved through the regional regulation, namely: a. creating an orderly, clean, beautiful, comfortable, and safe atmosphere for the street vendors' business; b. improve community welfare through the development of community informal sector trading activities; c. realizing an integrated arrangement of street vendors in a harmonious, harmonious and balanced manner with sustainable spatial planning; and D. increase community participation in structuring and fostering street vendors.

The stipulation of the policy of structuring street vendors through regional regulation No. 3 of 2014 shows that there is progress in seeing the existence of street vendors. The Municipal Government of Padang unconsciously places street vendors as a source of public disorder so that it is one of the activities that need to be regulated in the Padang City Regional Regulation number 11 of 2005 concerning Public Order and Public Peace. It is quite a long period of time used by the city government of Padang to realize that there is an inaccurate perspective of seeing street vendors.

For 10 years, it took the Padang City government to realize that this point of view was inaccurate. The Padang City Government has changed its perspective (mindset) in understanding the existence of street vendors as part of the city's economic system. Street vendors are no longer seen as a source of chaos and disorder in the city, but are considered part of the city's economic system.

Until now, perda no 3 of 2014 has entered its 5 year anniversary, various practices of implementing regional regulations have been carried out. This paper was written to explain the good practices adopted by the city government in implementing the policy of structuring and empowering street vendors in the city of Padang.

Papers are prepared based on research carried out using quantitative research methods. The population of this research is street vendors. The sample size was 49 street vendors who were taken using purposive sampling technique. The data were collected using a questionnaire. The collected data were analyzed using descriptive analysis method using frequency tables. The research was conducted in the city of Padang.
Street vendors are a form of activity in the informal sector. The Padang City Government regulates the existence of street vendors in Padang City Regional Regulation Number 3 of 2014 concerning Structuring and Empowering Street Vendors. Street vendors are business actors who carry out trading businesses using mobile or immovable business facilities, using city infrastructure, social facilities, public facilities, land and buildings owned by the government and / or private companies that are temporarily not permanent.

Five times traders have different characteristics from traders in other formal sectors [1]. Yustika (2001) describes street vendors as a marginalized and powerless group of people who basically have a weak bargaining position against various actions that discriminate against them [2].

Good practice is basically the implementation of a policy. Policy is a series of actions that are determined and implemented or not implemented by the government which are oriented towards certain goals for the overall interest of society [3]. Policy can be carried out in general, but in fact it is more often and widely used in government actions or behavior and state behavior. Policy in this context is better known as state policy or public policy (public policy). Public policy is whatever the government chooses to do or not do [4].

Edward and Sharkansky (in Islamy, 1998) understand public policy as anything that is chosen by the government to do something or not to do something, meaning that public policy can only be made by the government, not private organizations and that public policy is about the choice to make or not. conducted by the government [5]. Public policies can be in the form of Laws, Government Regulations, Provincial Government Regulations, City / Regency Government Regulations, and Mayor / Regent Decrees [6].

Policies are set to achieve certain goals. Policy is a series of actions that have a specific purpose which is followed and carried out by an actor or group of actors in order to solve a particular problem [7]. The objective of policy is in principle to intervene. Policy implementation is actually the action of the intervention). The success of a public policy implementation is determined by the level of policy implementability itself, which consists of content of policy and context of policy [8].

The implementation of a policy can be analyzed using several policy implementation models. One of the policy implementation models is a model developed by van Meter and van Horn which is called a model of the policy implementation process [9]. This model tries to connect policy issues with implementation and a conceptual model that links policy to work performance. Between policies and work performance are separated by a number of independent variables which are interrelated.

Various studies regarding the arrangement of street vendors as a public policy of the city government are not always welcomed by street vendors so that they do not give satisfactory results. The results of Evita's 
(2013) research show that the implementation of the street vendor arrangement policy at Batu Tourism Center is an unsuccessful implementation [10]. Likewise, the research results of Dewi and Yunuardi (2013) regarding the implementation of the arrangement of street vendors in the Malioboro area show that there are still some very basic weaknesses in its implementation [11].

The guidance carried out by the government is often perceived by street vendors as eviction without providing a solution that can increase the income of street vendors. This perception causes government policy to initially be responded negatively by street vendors. This negative response caused the program to be unsuccessful even though the program was actually very profitable for the street vendors.

The failure to implement government policies and programs in developing street vendors can basically be seen from three things, namely in terms of communication between government officials and street vendors, involvement of supervisors, and the basis for guidance. In terms of communication, the government often provides guidance using a supply-side-oriented approach without communicating and cooperating with street vendors themselves. Meanwhile, in the implementation of policies for street vendors, the government often involves various security forces which can lead to perceptions of war against street vendors. Meanwhile, the basis for controlling and controlling street vendors is based more on the involvement of the government in project implementation than on the spirit of developing the informal sector as one of the bases for the people's economy.

The existence of street vendors can cause inconvenience to the surrounding traffic. Local governments have the authority to regulate these problems to create good governance in accordance with the principles of good governance [12]. Ahkam's research shows that. the arrangement program for street vendors in Bondowoso Regency is already good, but not maximized [13]. In the structuring program that is being carried out there are still various obstacles, both internal and external, so that the government's desire to create a city that is neat, clean, comfortable and safe has not been achieved.

The Regional Government of Gowa Regency has implemented a good practice in structuring street vendors by providing business premises for street vendors in the form of kiosks that have been arranged based on the types of sales of the traders. Besides that, it also provides guidance to traders for the benefit of business development and improving the welfare of street vendors and carries out supervision [14].

The zoning policy implemented by the Bandung City government greatly impacts the welfare of street vendors, street vendors can sell neatly, orderly, safely and comfortably, and their income increases [15]. The sidewalks in the Kota Tua Jakarta area are considered successful by involving relevant stakeholders. The obstacles faced in implementing this policy are the growing number of illegal traders, discipline of cooperative member traders and inadequate facilities and infrastructure.

\section{RESEARCH RESULTS AND DISCUSSION}

\subsection{Street Vendors Arrangement}

The effort to organize street vendors by the Padang city government is carried out by means of various policies stipulated in regional regulations through the obligation of traders to register a business. Traders are also given rights and obligations that must be carried out in the context of orderliness, location and time of trading as well as fees that must be paid as a source of regional income.

The place to trade street vendors is legally determined by the Padang city government, which is permanent and temporary. The number of street vendors who live in the location permanently is $22(44.9 \%)$ and the temporary ones are $27(55.1 \%)$. Places that are temporary in nature can still be moved if needed by the government, even though they have been determined and protected by regional regulations. This figure shows that street vendors are very vulnerable and have a very low bargaining position with the city government.

Trading needs to have certainty of a permanent place so that it can make it easy for customers to find it. The street vendors who trade for a long time depend on regular customers who have been built since they started trading. Frequent transfers make traders lose customers. Losing customers causes a decrease in the income of street vendors.

The type of place of business cannot be made permanently. Traders are not allowed to build their place of business permanently in a predetermined location, even though that place has been permanently assigned.

Street vendors are very flexible traders, they usually trade anything where they are. The government does not limit the types of merchandise that are allowed to be held in the space provided. The business fields developed by street vendors are very diverse, although most of them are clothing and culinary businesses.

Every trader is required to make a business registration certificate issued by the Padang city government. These provisions are intended to guarantee legal certainty in terms of the location or place where they trade. This provision is also intended to ensure certainty for the authorized official to collect retribution at the designated location and control measures. The control should be carried out in another location outside the street vendor's place which already has a business registration certificate.

The existence of a business registration sign is very profitable for street vendors because it can make traders calmer and more comfortable trading. Concerns about being disciplined and being asked for illegal fees by unauthorized persons are guaranteed through the registered business. Unfortunately, many street vendors do not know this provision so they don't want to take 
care of it. The majority $(53.1 \%)$ of the street vendors surveyed said they did not know that to become a street vendor must have a business registration certificate, while $23(43.9 \%)$ knew this provision.

The number of street vendors who do not know that they are required to have a business registration certificate is because the dissemination of local regulations governing this matter is less intensive. Only $14(28.6 \%)$ street vendors surveyed had received dissemination regarding the regulations regarding the need to have a business registration certificate for street vendors, while the majority of 35 (71.4\%) street vendors had never participated in any dissemination regarding the obligation to have a business registration certificate. list of these businesses.

Lack of dissemination regarding the need to have a business registration certificate for street vendors has an impact on the number of traders who have a business registration certificate. Only $6(12.2 \%)$ street vendors have a business registration certificate, while the majority of $43(87.2 \%)$ street vendors do not have a business registration certificate. There are several reasons put forward by street vendors who do not have a business registration certificate, namely the requirements do not meet, the difficulty in managing it, and the business registration sign is not important or useless. The description of the reasons put forward by street vendors for not wanting to take care of the business registration certificate confirms that the dissemination by the city government on regulations related to the business registration certificate is still not intensive. Not many street vendors understand the importance of having a business registration mark for the continuity of their business.

Registered street vendors are given the rights and obligations that must be carried out. These rights and obligations are contained in local regulations. According to the assessment of most street vendors, not all of them have received the rights as stipulated in the regional regulation. Of the 5 rights that should be obtained by street vendors according to the regional regulations of the city of Padang, only two rights according to most street vendors have been obtained, namely the right to do business in a predetermined location and to obtain information and socialization or notification related to business activities at the location. concerned.

The right to get assistance in obtaining capital loans with bank partners has not been obtained by most street vendors (67.3\%). This condition reinforces the picture that the street vendors' working capital is mostly from themselves, very few rely on loan capital from banks.

In addition to the rights given to street vendors through these regional regulations, street vendors are also burdened with obligations that must be carried out. In terms of the obligation to comply with statutory provisions, most $(65.3 \%)$ said they were compliant. This shows that basically the street vendors are traders who are willing to comply with the provisions imposed by the blood government.

The obedience of street vendors to the provisions in regional regulations is shown by their willingness to maintain the beauty, order, security, cleanliness and health of the business environment. Most of the street vendors $(69.4 \%)$ said they wanted to maintain the beauty, order, security, cleanliness and health of the business environment. In terms of the obligation to comply with the timing of business activities, not all street vendors have carried out their obligations. There are $32.7 \%$ of street vendors who are not obedient in complying with the time for business activities set by the Mayor, while $12.2 \%$ are not obedient. The street vendors often steal a start in holding merchandise before the set start time. Steal the start of the trading time is usually used to organize merchandise and prepare merchandise.

In general, the street vendors occupy a location close to the road so that they are likely to disrupt traffic. The obligation of street vendors to regulate their merchandise and trading activities so as not to disturb traffic. This obligation can not always be fulfilled, there are still street vendors whose trade disrupts traffic.

The location where the street vendors trade is basically temporary. The Padang City Government has determined zoning for street vendors, but the zoning can be converted from time to time. Street vendors at any time can be evicted and the place can be used for other purposes. The street vendors have an obligation to surrender the place when the city government needs it, but most of the street vendors do not want to surrender. Retribution is an obligation that must be paid by street vendors. However, not all street vendors are willing to pay for it. The official rate for retribution is Rp. 11,000/ day / trader. Merchants did not always pay the same amount of retribution. There are various variations in the amount of fees paid by street vendors, namely from Rp. 2,000 to Rp. 100,000.

\subsection{Street Vendors Empowerment}

The government has implemented several policies in order to empower street vendors. These policies are in the form of capital, development of street vendor organizations, cooperatives, technical guidance communication. The implementation of this policy is still not widely known by street vendors. Most of the street vendors do not feel that they have ever enjoyed the implementation of the policies that have been made. The government has also made various efforts to improve facilities and infrastructure, increase the area or number of street vendors, change zoning and change schedules and types of business. This business also seems to have not been evenly enjoyed by street vendors. Some of the street vendors feel they don't get what the city government has done.

2.3. Good Practices Arrangement and Empowerment of Street Traders

Basically the city government has made efforts to organize and empower street vendors in the 
city of Padang. Government actions in the context of structuring and empowering street vendors are not always considered a good practice by street vendors.

The actions of the city government that are considered by most street vendors as a good practice are locating the street vendors, increasing their business skills/training, increasing communication forums between street vendors, improving facilities and markets, adding or reducing the location of street vendors, coaching. street vendor organizations, fostering and developing street vendors cooperatives. Actions related to relocation, closure, zoning changes, changes in trading schedules are considered largely unsuitable practices by the city government. Meanwhile, access to capital for business development, addition or reduction of the location of the street vendors, technical guidance and guidance by most street vendors is considered not yet implemented.

2.4. Objectives of Structuring and Empowerment

Basically, the goal of structuring and empowering street vendors is very good, although there are still some things that have not been achieved. Objectives related to the arrangement of street vendors (creating an orderly atmosphere of the street vendors 'business places, creating a clean atmosphere for street vendors' business places, creating a beautiful atmosphere of street vendors 'business places, creating a comfortable atmosphere of street vendors' business places, creating the atmosphere where the street vendors business is safe) is considered to be achieved by the city government.

The goals related to empowerment are still deemed not achieved by street vendors (improving community welfare through the development of informal sector trading activities development of community informal sector trading activities), meanwhile, empowerment in realizing an integrated arrangement of street vendors in a harmonious, harmonious and balanced manner with Sustainable spatial planning and increasing community participation in structuring and fostering street vendors is considered by street vendors to be realized.

\section{CONCLUSION}

The good practice of structuring and empowering street vendors begins with changes in government policies that place street vendors as a source of urban disorder (Padang city regional regulation number 11 of 2005 concerning public order and public order) as part of the city's economic system (perda no 32014 concerning structuring and empowering street vendors).

The implementation of the policy is considered by street vendors to emphasize more on structuring rather than empowering street vendors. The goal is to create a clean, orderly, beautiful, comfortable, safe place for the street vendors' business, to create an integrated arrangement of street vendors in a harmonious, harmonious and balanced manner with sustainable spatial planning, and to increase community participation in the arrangement and development of street vendors is considered to have been achieved by street vendors. Meanwhile, the aim of the policy of structuring and empowering street vendors in terms of increasing welfare through the development of community informal sector trading activities is considered to have not been achieved.

\section{ACKNOWLEDGMENTS}

Thanks are conveyed to the Institute for Research and Community Service (LP3M), Andalas University for funding this research.

\section{REFERENCES}

[1] Jones, Charles O. Pengantar Kebijakan Pubik, PT. Raja Grafindo Persada. 1996.

[2] Dye, Thomas R, . Understanding Public Policy, Eleventh Edition, New Jersey: Pearson Prentice Hall. 2005

[3] Edward dan Sharkansky DALAM Islamy, M.Irfan. Prinsip-prinsip Perumusan Kebijaksanaaan Negara. Jakarta: Bumi Aksara. 1998.

[4] Subarsono, 2010, Analisis Kebijakan Publik: Konsep, Teori, dan Aplikasi, Yogyakarta: Pustaka Pelajar

[5] Anderson, James E. 1979. Public Policy Making. Boston: Houghton Mifflin.

[6] Widodo, J. Analisis KebijakanPublik: Konsep dan Aplikasi Analisis Proses Kebijakan Publik.Malang: Bayu Media Publishing. 2013

[7] Evita, E. Implementasi Kebijakan Penataan Pedagang Kaki Lima (Studi Pada Batu Tourism Center Di Kota Batu). Jurnal Administrasi Publik, 1, (5), 2013. 943-952.

[8] Evita, E. Implementasi Kebijakan Penataan Pedagang Kaki Lima (Studi Pada Batu Tourism Center Di Kota Batu). Jurnal Administrasi Publik, 1, (5), 2013. 943-952.

[9] Dewi, P., Yanuardi, Y. Implementasi Kebijakan Penataan Pedagang Kaki Lima Di Kawasan Malioboro Yogyakarta. Jurnal Adinegara, 7, (1), 2013. 1-14.

[10] Erlinda, R.D., Sutji, A.B.D.D., Indrayati, R. "Kajian Yuridis Tentang Izin Pedagang Kaki Lima di Jalan Jawa Untuk Mewujudkan Penyelenggaraan Pemerintahan Yang Baik (Good Governance) di Wilayah Kabupaten Jember". E-Journal Lentera Hukum, 1, (1), 2014. 33-42.

[11] Ahkam, H. "Program Penataan Pedagang Kaki Lima (PEDAGANG KAKI LIMA) di Wilayah Perkotaan (Studi Pada Pemerintah Daerah Kabupaten Bondowoso)". Jurnal Administrasi Publik, 3, (9), 2015. 1548-1552.

[12] Handam, H., Tahir, M.M.Peran Pemerintah Daerah dalam Pelaksanaan Penataan Pedagang Kaki Lima di Pasar Minasamaupa Kabupaten Gowa. Otoritas : Jurnal Ilmu Pemerintahan, 6 (1), 2016. 28-41.

[13] Ramadhan,. Adam, "Implementasi Model Zonasi Penataan Pedagang Kaki Lima di Kota Bandung", Pandecta. Volume 10. Nomor 1. Januari 2015 
[14] Sujatna, Yayat. "Implementasi Kebijakan Penataan Pedagang Kaki Lima di Kawasan Kota Tua Jakarta, JPM (Jurnal Pemberdayaan Masyarakat)", ISSN : 25411977 E- ISSN : 25411977 Vol. 3 No. 2

2018, 2018.

http://ejournal.unikama.ac.id/index.php/jpm 